\title{
Europe in 2018: Less Populist, More Popular?
}

A year ago, Europe seemed to be under siege by populist forces. Polls pointed to electoral breakthroughs by the Front National in France, the Freedom Party in the Netherlands and the AfD in Germany. The worst of those fears proved unfounded.

Marine Le Pen was never going to win the presidency of France, but there was a real risk that the margin could be alarmingly narrow. In the end, Emmanuel Macron's victory was all the more remarkable for his enthusiastic embrace of the idea and the symbols of Europe. In the Netherlands, Geert Wilders' Freedom Party ended up a distant second - though his hard-line stance on immigration had been to some extent internalised by other parties. In Germany, Chancellor Merkel won a fourth consecutive victory, but this striking achievement was marred by the entry of the AfD into the Bundestag, the first time since the 1950s that a far-right party had been present in the German parliament. And of course in Austria, while the Freedom Party ended up in third place, it is the junior partner in a ruling coalition. In short, while Europe's far-right surge has stalled, the populist threat has certainly not gone away.

This has been a year of good news on the economic front. But Europe still faces significant challenges. The euro area economy is on track to grow at its fastest pace in a decade. Unemployment in the euro area has fallen to its lowest level since January 2009. Moreover, public finances have improved, with the average deficit in the euro area set to fall below one per cent of GDP in 2018, down from over six per cent in 2010. However, many parts of the euro area still face high public and private debt, high long-term and youth unemployment, weak wage growth, or pockets of financial vulnerability. In short, behind the encouraging developments we see overall, there are persistent divergences between euro area economies.

How should we face these challenges in 2018? Importantly, we cannot pander to the extremists by internalising their messages and policies. I believe we need to deliver convincing policy solutions to achieve more social justice and fight inequality. This means pursuing three priorities in 2018.

Greece. I am very optimistic that the Greek programme can conclude successfully next summer and that Greece can move on to a new chapter. All the institutions involved in the programme now expect Greece to exceed by a wide margin its primary surplus target for 2017. We are also confident that Greece's 2018 budget will enable Greece to meet its primary surplus target in 2018. The Greek people have made enormous sacrifices to turn that situation around, to restore stability to their country and to safeguard its place in the euro area. The latest review of the programme has progressed more swiftly and smoothly than perhaps any other. This bodes well for the strategic discussions we will need to have in 2018 as we look towards the conclusion of the programme. Two questions should drive our work going forward. How do we support a successful growth strategy, which will be Greek-owned and Greek-led? And how do we enable Greece to fully regain its economic sovereignty while ensuring that reform implementation proceeds, especially in the immediate post-programme years? Both are key to ensuring a brighter and more stable future for Greek citizens.

Deepening EMU. The Commission firmly believes that the euro is a force for unity, not division, on our continent. In December we proposed to strengthen the governance of the Economic and Monetary Union through strong legal and institutional initiatives, with the 
creation of the European Monetary Fund and the establishment of a European Economy and Finance Minister. At the same time, we propose to strengthen budgetary and financial support for convergence between EMU economies through support for structural reforms and new tools to better equip the euro area and the whole of Europe. This includes, crucially, a proposal for a stabilisation function, which will help countries to deal with asymmetric shocks. This package will not be the last step we need to take to deliver the stronger, more efficient, more democratic EMU we need. But it is an important contribution to the discussion that we will be engaged in with our member states in the months ahead.

Taxation. In recent years, there have been a string of tax scandals, and they call for swift action. Since the beginning of my tenure at the Commission, I have pushed for a complete paradigm shift from a culture of secrecy to tax transparency, from silos to cooperation between administrations. We are beginning to reap the benefits of this change. Banking secrecy has disappeared throughout Europe since 2017, including in Switzerland and Liechtenstein. Automatic information exchange has started to apply. From 2019 onwards, a number of key anti-abuse measures that will eliminate the most common tax evasion schemes will come into force. But we still have much to do to enact this agenda of efficiency and transparency. In 2018 I will focus on three initiatives:

- First, we must press member states to agree on the new transparency rules we have proposed for tax intermediaries. They should systematically declare to the tax authorities of their client's country any tax optimisation schemes that meet certain characteristics. If these schemes are illegal, the tax authorities will be able to take legal action. If they are legal, tax authorities will be able to identify regulatory loopholes and fix them.

- Second, we must keep up the pressure on tax havens to change their ways. An important milestone was reached in December with the adoption of the first European "blacklist" of tax havens. This list is complemented by a "grey list" of over 40 jurisdictions that have undertaken to change their tax legislation. The countries that have taken commitments must change their tax laws as soon as possible, and dissuasive sanctions must be adopted by member states.

- Finally, it is the absence of common rules in Europe that allows companies to engage in aggressive tax planning. A common corporate tax base would limit artificial transfers of profits between countries. This ball is in the court of our member states. They should accelerate these discussions and bring them to a positive conclusion in 2018 .

Pierre Moscovici, European Commissioner for Economic and Financial Affairs, Taxation and Customs, Brussels, Belgium.

As we look ahead to 2018, we must be fully aware that the war against nationalists and anti-European populists is far from over. This is a war that we can and must win. Not by renouncing our core values. Not by following the populists' agenda, which is a road to nowhere. But by proving to our citizens through our actions that Europe is still able to deliver real improvements to their lives.

Zbigniew Brzeziński once noted, "We have a large public that is very ignorant about public affairs and very susceptible to simplistic slogans by candidates who appear out of nowhere, have no track record, but mouth appealing slogans." These words still resonate today. But I refuse to see this "large public" as a lost cause. Their hearts and minds can still be won - if we have results to show for our policies. Let us bear this mind and move forward into 2018 with determination. 